\title{
Relation between type and local of orthopedic injuries with physical activity in horses
}

\author{
Nicole Ruas de Sousa ${ }^{{ }^{*}}$ Stelio Pacca Loureiro Luna ${ }^{1}$ Dietrich Pizzigatti $^{1}$ \\ Mayra Teixeira Alas Martins ${ }^{2}$ Fabio Sossai Possebon ${ }^{3}$ Adriana Cristina Saldanha Aguiar ${ }^{4}$
}

\footnotetext{
${ }^{1}$ Departamento de Cirurgia e Anestesiologia Veterinária (DCAV), Faculdade de Medicina Veterinária e Zootecnia (FMVZ), Universidade Estadual Paulista (UNESP), 18618-681, Botucatu, SP, Brasil. E-mail: nicole@fmvz.unesp.br. "Corresponding author.

${ }^{2}$ Departamento de Clínica Veterinária, Faculdade de Medicina Veterinária e Zootecnia (FMVZ), Universidade Estadual Paulista (UNESP), Botucatu, SP, Brasil.

${ }^{3}$ Departamento de Higiene Veterinária e Saúde Pública, Faculdade de Medicina Veterinária e Zootecnia (FMVZ), Universidade Estadual Paulista (UNESP), SP, Brasil.

${ }^{4}$ Departamento de Reprodução Animal e Radiologia Veterinária, Faculdade de Medicina Veterinária e Zootecnia (FMVZ), Universidade Estadual Paulista (UNESP), SP, Brasil.
}

\begin{abstract}
Equine sport modalities influence the prevalence and predisposition of musculoskeletal injuries in horses. This study aimed to evaluate the prevalence of location and type of orthopedic injuries of horses undergoing various physical activities. Data from 116 horses of different breeds and ages was analyzed. Physical activities included dressage, racing, polo pony, jumping, work and western performance. All horses had history of orthopedic lameness diagnosed by radiographs and/or ultrasound scans. The effect of sport on the affected anatomical site and type of lesion was performed using Fisher's exact test. Desmitis was more prevalent in animals that performed western sports than in the working ones. The number of fractures was greater in racing and polo pony animals than in working horses. Stifle lesions were more prevalent in dressage horses than working horses and had lower occurrence of shoulder injuries than jumping horses. Hind limb tendon injuries were lower in jumping than in dressage and western horses. We conclude that there is a relationship between location and type of injury and physical activities. In racing horses there is a predominance of young animals and higher prevalence of orthopedic injuries from traumatic events such as tendonitis, desmitis and fractures. In physical activities that require longer training and that animals were used for longer periods, eg. jumping, polo pony, dressage and work, age-related degenerative, such as joint disease, were predominant. In western sport animals the most common lesion was desmitis. Regarding limbs, forelimb injures were more often observed in racing horses, polo pony, jumping and working animals; whereas, dressage and Western sports horses presented more injuries in hind limbs.

Key words: horses, athletic injuries, arthropathy, tendinopathy.
\end{abstract}

\section{Relação do tipo e local de lesões ortopédicas com a atividade física em equinos}

RESUMO: As modalidades esportivas influenciam a prevalência e predisposição de lesões musculoesqueléticas em cavalos. Objetivou-se avaliar a prevalência do local e tipo de lesões ortopédicas de cavalos submetidos a diversas atividades fisicas. Foram avaliados 116 prontuários de equinos de adestramento, corrida, polo, salto, trabalho e Western, de raças e idades variadas, com histórico de claudicação e confirmação do diagnóstico por radiografia ou ultrassonografia da lesão ortopédica. O efeito da atividade fisica sobre o sitio anatomico afetado e tipo de lesão foi avaliado pelo teste Exato de Fisher. A desmite foi mais prevalente em animais de Western quando comparada com animais de trabalho. Fratura foi maior em Corrida e Polo comparado com Salto; e maior em Corrida comparado com Trabalho. As alterações fêmoro-tíbio-patelares foram mais prevalentes em adestramento do que trabalho e estes apresentaram menor ocorrência de lesões de articulação escápulo-umeral que os de salto. As lesões tendíneas de membros pélvicos foram menos prevalentes nos animais de salto do que nos de adestramento e Western. Conclui-se que há uma relação entre local e tipo de lesão com as atividades fisicas. No turfe, há um predomínio de animais jovens e maior prevalência de lesões ortopédicas provenientes de eventos traumáticos, como tendinite, desmites e fraturas. Em atividades fisicas que requerem um treinamento mais prolongado e que os animais são usados por mais tempo, como os de salto, polo, adestramento e trabalho, predominam lesões degenerativas relacionadas à idade, como doença articular. Em animais de Western, predominam as desmites. Quanto à porcentagem das injúrias ortopédicas distribuidas pelos membros, preponderam alterações em membros torácicos nos animais de turfe, polo, salto e trabalho e nos membros pélvicos nos animais de adestramento e de Western. Palavras-chave: cavalos, lesões esportivas, artropatia, tendinopatia.

\section{INTRODUCTION}

Sport and training program influence the prevalence and predispose musculoskeletal injuries and lameness in horses (EVANS \& WALSH, 1997; MURRAY et al., 2006; MENARIM et al., 2012; TIPTON et al., 2013), depending on the work overload on specific anatomical structures also related to the type of sport and level of training (MURRAY et al., 2006).

Lameness affects performance has negative economic consequences and impacts animal's athletic career, and it can cripple its use in sports (EVANS \& WALSH, 1997; COUROUCÉ-MALBLANC et al., 2006; MENARIM et al., 2012). Early detection of musculoskeletal injuries helps to prevent new lesions, and 
some animals can still obtain high athletic performance if injures are treated properly (SCHOEN, 2000; DYSON, 2002; MENARIM et al., 2012; RAMZAN et al., 2013). Therefore it is important to determine the prevalence of lesions that cause lameness in specific sports and that affect the horse use (MENARIM et al., 2012).

In horses used in different activities, $46 \%$ presented lesions in the distal limbs, which occurred during the exercise, and the incidence was twice higher in competing horses than those who did not compete (OWEN et al., 2012). There is a predominance of suspensory ligament injuries in jumping, dressage and eventing horses (MURRAY et al., 2006). Racing French Trotters had a high prevalence of abnormal radiographic findings, of which $18 \%$ were in the metatarsophalangeal region and $11 \%$ proximal tarsus (COUROUCÉ-MALBLANC et al., 2006). In dressage horses, the most common injuries were suspensory ligament desmitis and degenerative joint disease (DJD) in the tarsal-metatarsal and carpalmetacarpal joints (DYSON, 2002).

Several studies have reported risk factors of injuries in dressage horses (MURRAY et al., 2006; RIGGS, 2010), eventing (MURRAY et al., 2010), racing ((BAILEY et al., 1997; PARKIN, 2008), and general purpose horses (OWEN et al., 2012).

Injury prognosis is not the same for different athletic disciplines even if they are in the same anatomical site. Thus recognizing what is involved in training and management of horses of certain activities, can help rehabilitation programs (DYSON, 2002).

Based on the hypothesis that physical activity is correlated to orthopedic injuries in horses, we aimed to evaluate the prevalence of location and type of orthopedic injuries in horses undergoing various physical activities such as dressage, racing, polo pony, jumping, working and western performance.

\section{MATERIALS AND METHODS}

Clinical cases of 116 horses of various breeds and ages were evaluated, Each one had history of lameness which was diagnosed through radiographs and/or ultrasound examination. All cases dated from January 2012 to August 2014.

Diagnoses were categorized according to anatomical site affected and type of lesion, as follows: desmitis, tendonitis, bone reaction (sesamoiditis, pedal osteitis, navicular disease, and the distal interphalangeal osteoarthritis), joint disease (articular osteoarthritis), fracture, muscle injury (stretch), others (abscess, laminitis, low back pain or wounds). Animals were categorized into groups according to physical activity performed: dressage, racing horse, polo pony, jumping, working (guard, carousel and pull) and western sports (cutting and barrel).

The statistic method used to evaluate lesions type and location in each sport was Fisher's exact test. Statistical analysis was performed comparing physical activities in pairs. To compare age among physical activities, analysis of variance was used. Fisher's exact test was also used to compare sex and race among physical activities, with a significance level of 5\% $\left(\mathrm{SAS}^{\circledR}\right.$ and GraphPadInstat ${ }^{\circledR}$ 3:05).

\section{RESULTS}

Physical activities that did not have significant difference among them, were not described in the results and therefore injuries occurrence was similar. Of the 116 animals, $43 \%$ were female and $57 \%$ male. The number of females was higher in polo pony activities and western performance. In racing, jumping and working activities there was a higher number of males. In dressage, the number of males and females was similar. Racing animals were younger, with an average of $3 \pm 1$ years old, while polo pony, jumping and working horses were the oldest with an average of 11-14 years old.

Distribution of orthopedic injuries according to physical activity is presented in table 1. Desmitis was more prevalent in western sport animals (39\%) compared to working $(14 \%, \mathrm{P}=0.04)$. Racing horses $(27 \%)$ had a higher incidence of tendinitis compared to western ones $(0 \%, \mathrm{P}=0.03)$. Fractures were reported more often in racing $(27 \%)$ than working $(4 \%, \mathrm{P}=0.02)$ and jumping horses $(2 \%, \mathrm{P}=0.005)$, and in jumping horses the occurrence of fractures was lower than in polo pony $(19 \%, \mathrm{P}=0.02)$.

Percentage of anatomical sites affected according to physical activity is presented in table 2 . Femoraltibial-patellar lesions were more frequent in dressage $(20 \%)$ than working horses $(2 \%, \mathrm{P}=0.04)$. Working horses $(10 \%)$ presented lower incidence of scapularhumeral injuries than jumping horses $(0 \%, \mathrm{P}=0.01)$. Hind limbs tendinopathies were less common in jumping $(2 \%)$ than dressage $(20 \%, \mathrm{P}=0.02)$ and western sports horses $(17 \%, \mathrm{P}=0.04)$.

Due to the low number of animals it was not possible to assess the relative risk of injuries based on physical activity through using logistic regression.

\section{DISCUSSION}

A direct relationship between the type of physical activity and orthopedic injuries in horses 
Table 1 - Number and frequency of orthopedic injuries occurrence in 116 horses undergoing different physical activities.

\begin{tabular}{|c|c|c|c|c|c|c|c|c|c|c|c|c|}
\hline & \multicolumn{4}{|c|}{-------dressage-------- --------racing------- } & \multicolumn{2}{|c|}{-----polo pony---- } & \multicolumn{2}{|c|}{------jumping----- } & \multicolumn{2}{|c|}{------working----- } & \multicolumn{2}{|c|}{-------western------- } \\
\hline & $\mathrm{n}$ & $\%$ & $\mathrm{n}$ & $\%$ & $\mathrm{n}$ & $\%$ & $\mathrm{n}$ & $\%$ & $\mathrm{n}$ & $\%$ & $\mathrm{n}$ & $\%$ \\
\hline Desmitis & 4 & $27 \% \mathrm{ab}$ & 4 & $27 \% \mathrm{ab}$ & 2 & $13 \% \mathrm{ab}$ & 11 & $18 \% \mathrm{ab}$ & 7 & $14 \% \mathrm{a}$ & 7 & $39 \% \mathrm{~b}$ \\
\hline Tendonitis & 2 & $13 \% \mathrm{ab}$ & 4 & $27 \% \mathrm{a}$ & 2 & $13 \% \mathrm{ab}$ & 8 & $13 \% \mathrm{ab}$ & 8 & $16 \% \mathrm{ab}$ & 0 & $0 \% \mathrm{~b}$ \\
\hline Bone reaction & 2 & $13 \%$ & 0 & $0 \%$ & 1 & $6 \%$ & 15 & $24 \%$ & 8 & $16 \%$ & 3 & $17 \%$ \\
\hline Joint disease & 7 & $47 \%$ & 3 & $20 \%$ & 7 & $44 \%$ & 18 & $29 \%$ & 18 & $37 \%$ & 6 & $33 \%$ \\
\hline Fracture & 0 & $0 \% \mathrm{abc}$ & 4 & $27 \% \mathrm{a}$ & 3 & $19 \% \mathrm{ab}$ & 1 & $2 \% \mathrm{c}$ & 2 & $4 \% \mathrm{bc}$ & 1 & $6 \% \mathrm{abc}$ \\
\hline Muscle injury & 0 & $0 \%$ & 0 & $0 \%$ & 0 & $0 \%$ & 0 & $0 \%$ & 3 & $6 \%$ & 0 & $0 \%$ \\
\hline Others & 0 & $0 \%$ & 0 & $0 \%$ & 1 & $6 \%$ & 9 & $15 \%$ & 3 & $6 \%$ & 1 & $6 \%$ \\
\hline Total & 15 & $100 \%$ & 15 & $100 \%$ & 16 & $100 \%$ & 62 & $100 \%$ & 49 & $100 \%$ & 18 & $100 \%$ \\
\hline
\end{tabular}

*Percentages followed by the same letter do not differ between them by Fisher`s exact test, for $\mathrm{P}<0.05$, in the comparison physical activities, by orthopedic injury.

was observed. Our results corroborate previous studies conducted in other countries (CHENEY et al., 1973; MEERSHOEK et al., 2001; DYSON, 2002; DABAREINER et al., 2005; MURRAY et al., 2006; DYSON, 2007; COGGER et al., 2008; SCOTT, 2008; MURRAY et al., 2010; MENARIM et al., 2012) and it can be useful in identifying risk factors to these injuries, to propose changes in management, handling and training in order to prevent losses, suffering of animals and financial losses.

Jumping and working horses were the oldest ones, similar to that reported in a previous study (MURRAY et al., 2006), suggesting that these animals require longer training periods (MITCHELL, 2013), and, like working animals, they retired later in life.

Jumping horses are required to jump obstacles accurately at a given speed and being capable of making sharp turns, sometimes in gallop (DYSON, 2002). When landing after a jump, the ground reaction force against the forelimbs is much higher when compared to normal trot (SCHAMBARDT et al., 1993; MEERSHOEK et al., 2001; MURRAY et al., 2006). Besides, the movement of third phalange inside the hoof has an important role on the limb stance and shock absorption during landing (MITCHELL, 2013). Hence probably lesions in the thoracic limbs are higher than in the pelvic ones. This was observed in this study and in the literature, in which the most affected regions were metacarpophalangeal, thoracic flexor tendons and hooves (DYSON, 2002; BOSWELL et al., 2003; MURRAY et al., 2006). An increased tendency for bone reactions such as sesamoiditis and osteitis was also observed in racing animals and desmitis in western sports horse, as previously reported (MURRAY et al., 2006), which also present higher occurrence of navicular disease and suspensory ligament injuries.
Jumping horses had a tendency to present more metatarsophalangeal lesions when compared to working animals. Such injuries can be associated to the starting, which increases the load on the suspensory apparatus of the pelvic limbs.

In dressage, the horse must be obedient to the rider's commands. This modality exercises strengthens the muscles, especially around the joints. The dressage horse must shift its center of gravity to the caudal region, which overloads the hind limbs (DYSON, 2002). In this study, dressage horses were more affected in the femoral-tibial-patellar joints than working animals and in the hind tendons than jumping horses. These findings are justified by the overload on the hind limbs required in this modality, with center of gravity change and the increased time spent with the hind limbs engaged, to perform the movements of the forelimbs (DYSON, 2002; KOLD \& DYSON, 2003; MURRAY et al., 2006; MARNERIS \& DYSON, 2014).

There is a common occurrence of muscle injuries by fatigue in racing horses (DABAREINER et al., 2005; MENARIM et al., 2012) and previous studies reported increased risk of tendon injury in forelimbs (WILLIAMS et al., 2001), and carpal and pelvic fractures (POOL \& MEAGHER, 1990; PILSWORTH et al., 1994; MURRAY et al., 2006; DALLAS, 2013). This study also showed a higher incidence of fractures compared to working and jumping animals. Racing horses were also more likely to suffer from carpal injuries than in western sport, polo pony, working and jumping horses. They also presented more thoracic tendons injuries than western sports, polo pony and jumping animals, corroborating previous findings (POOL \& MEAGHER, 1990; PILSWORTH et al., 1994; WILLIAMS et al., 2001; DABAREINER et al, 2005; O'MEARA et al., 2010; MENARIM et al., 2012). 
Table 2 - Number and frequency of affected anatomical sites in 116 horses undergoing different physical activities.

\begin{tabular}{|c|c|c|c|c|c|c|}
\hline \multirow{2}{*}{ Site of injury } & \multicolumn{2}{|c|}{--------------Dressage------------- } & \multicolumn{2}{|c|}{----------------Racing-------------- } & \multicolumn{2}{|c|}{------------------Polo pony---------------- } \\
\hline & $\mathrm{n}$ & $\%$ & $\mathrm{n}$ & $\%$ & $\mathrm{n}$ & $\%$ \\
\hline Metatarsophalangeal & 1 & $7 \%$ & 0 & $0 \%$ & 2 & $12 \%$ \\
\hline Metacarpophalangeal & 3 & $20 \%$ & 3 & $20 \%$ & 2 & $12 \%$ \\
\hline Carpus & 0 & $0 \%$ & 3 & $20 \%$ & 1 & $6 \%$ \\
\hline Pelvic hoof & 0 & $0 \%$ & 0 & $0 \%$ & 0 & $0 \%$ \\
\hline Thoracic hoof & 0 & $0 \%$ & 0 & $0 \%$ & 2 & $12 \%$ \\
\hline Back & 0 & $0 \%$ & 0 & $0 \%$ & 0 & $0 \%$ \\
\hline Humerus-radio-ulnar & 0 & $0 \%$ & 0 & $0 \%$ & 2 & $12 \%$ \\
\hline Hip & 1 & $7 \%$ & 0 & $0 \%$ & 0 & $0 \%$ \\
\hline Stifle & 3 & $20 \% \mathrm{a}$ & 2 & $13 \% \mathrm{ab}$ & 0 & $0 \% \mathrm{ab}$ \\
\hline Metacarpus & 0 & $0 \%$ & 1 & $7 \%$ & 1 & $6 \%$ \\
\hline Metatarsus & 0 & $0 \%$ & 0 & $0 \%$ & 1 & $6 \%$ \\
\hline Scapulohumeral & 0 & $0 \% \mathrm{ab}$ & 0 & $0 \% \mathrm{ab}$ & 1 & $6 \% \mathrm{ab}$ \\
\hline Tarsus & 2 & $13 \%$ & 0 & $0 \%$ & 2 & $12 \%$ \\
\hline PelvicTendon/ligament & 3 & $20 \% \mathrm{~b}$ & 0 & $0 \% \mathrm{ab}$ & 1 & $6 \% \mathrm{ab}$ \\
\hline ThoracicTendon/ligament & 2 & $13 \%$ & 6 & $40 \%$ & 2 & $12 \%$ \\
\hline Total & 15 & $100 \%$ & 15 & $100 \%$ & 17 & $100 \%$ \\
\hline \multirow{2}{*}{ Site of injury } & \multicolumn{2}{|c|}{---------------Jumping------------- } & \multicolumn{2}{|c|}{---------------Working------------ } & \multicolumn{2}{|c|}{------------------Western----------------- } \\
\hline & $\mathrm{n}$ & $\%$ & $\mathrm{n}$ & $\%$ & $\mathrm{n}$ & $\%$ \\
\hline Metatarsophalangeal & 10 & $16 \%$ & 2 & $4 \%$ & 2 & $11 \%$ \\
\hline Metacarpophalangeal & 11 & $18 \%$ & 7 & $15 \%$ & 3 & $17 \%$ \\
\hline Carpus & 4 & $7 \%$ & 3 & $6 \%$ & 0 & $0 \%$ \\
\hline Pelvic hoof & 2 & $3 \%$ & 3 & $6 \%$ & 0 & $0 \%$ \\
\hline Thoracichoof & 9 & $15 \%$ & 4 & $8 \%$ & 1 & $6 \%$ \\
\hline Back & 2 & $3 \%$ & 0 & $0 \%$ & 0 & $0 \%$ \\
\hline Humerus-radio-ulnar & 1 & $2 \%$ & 0 & $0 \%$ & 0 & $0 \%$ \\
\hline Hip & 1 & $2 \%$ & 3 & $6 \%$ & 0 & $0 \%$ \\
\hline Stifle & 3 & $5 \% \mathrm{ab}$ & 1 & $2 \% \mathrm{~b}$ & 3 & $17 \% \mathrm{ab}$ \\
\hline Metacarpus & 2 & $3 \%$ & 2 & $4 \%$ & 1 & $6 \%$ \\
\hline Metatarsus & 1 & $2 \%$ & 0 & $0 \%$ & 0 & $0 \%$ \\
\hline Scapulohumeral & 0 & $0 \% \mathrm{a}$ & 5 & $10 \% \mathrm{~b}$ & 0 & $0 \% \mathrm{ab}$ \\
\hline Tarsus & 3 & $5 \%$ & 5 & $10 \%$ & 3 & $17 \%$ \\
\hline PelvicTendon/ligament & 1 & $2 \% a$ & 3 & $6 \% \mathrm{ab}$ & 3 & $17 \% \mathrm{~b}$ \\
\hline ThoracicTendon/ligament & 11 & $18 \%$ & 10 & $21 \%$ & 2 & $11 \%$ \\
\hline Total & 61 & $100 \%$ & 48 & $100 \%$ & 18 & $100 \%$ \\
\hline
\end{tabular}

*Percentages followed by the same letter do not differ between them by Fisher's exact test, for $\mathrm{P}<0.05$, in comparison with physical activities, by anatomical site.

Race horses reach high speeds and may suffer minor bone damage, which requires time to repair. During bone remodeling period, there is a temporary risk of osteoporosis because of osteoclast activity, leading to injuries predisposition (HERNANDEZ et al., 2001; RIGGS, 2002; STOVER, 2003; PARKIN, 2008; TURLEY et al., 2014), which explains the high incidence of fractures in racehorses. The function of the forelimbs is to absorb the impact during race, in which, the metacarpophalangeal and carpal joints are fully extended, and forced close to the pre-injury limit in proportion to the animal's speed. Thus, the soil force against the hoof propagates throughout the forelimb from the tendons to the carpus (CHENEY et al., 1973; BURN et al., 2006; O'MEARA et al., 2010; TURLEY et al., 2014), which explains the occurrence of the changes in carpal and thoracic tendons observed in this study.

Western performance includes reining, cutting, roping, barrel, among others, and the predominant breed used is the American Quarter Horse (DABAREINER et al., 2005; SCOTT, 2008; TIPTON et al., 2013), the same was observed in this study. During barrel racing, the horse performs a 
clover leaf pattern at gallop around three barrels. The horse has to accelerate and decelerate rapidly to make turns in different directions, usually in a time 15-17 seconds. Cutting horses and riders perform movements so they can keep a calf apart from the herd during a certain time. This requires quick stops and abrupt turns in an attempt to mirror the calf's movement and prevent it from returning to the herd (SCOTT, 2008; CONTINO et al., 2012). Signature moves of this activity include high-speed stops and abrupt changes of direction. These movements associated with the breed standard can lead to certain injuries. Contrary to previously reported (DABAREINER et al., 2005; MENARIM et al., 2012), this study reported higher incidence of pelvic tendons injuries and a tendency towards greater frequency of femoral-tibial-patellar and tarsus injuries in western sports animals than in jumping animals. There is a tendency to higher incidence of femoral-tibial-patellar injuries when compared to working animals (CONTINO et al., 2012; Smith (1993) apud TIPTON et al., 2013).

Tarsal osteoarthritis is a common disease among barrel racing horses (DABAREINER \& CARTER, 2003; DABAREINER et al., 2005; CONTINO et al., 2012; MENARIM et al., 2012). Training based on repeated and abrupt stops and turns, and the surface on which animals train and compete, are factors that influence the incidence of these injuries (SCOTT, 2008; CONTINO et al., 2012). This modality creates torque forces, compression and shear of the tarsus, while abruptly braking at high speed, sometimes with turns of up to $360^{\circ}$, generating forces that predispose to injury in the femoraltibial-patellar joints and pelvic tendons (SCOTT, 2008; MENARIM et al., 2012).

Reports of orthopedic injuries in polo animals are scarse and usually are related to high speed and impact between the club and the horse (LOBATO, 2013). The lameness prevalence in polo animals could be underestimated (BURDEN et al., 2013). Findings from this study were consistent with previous ones. This study demonstrated a higher rate of fractures in polo animals and a trend towards more muscle injuries, when compared to jumping animals (BAXTER, 2011), but rhabdomyolysis wasn't observed (McGOWAN et al., 2002). Another finding was that collisions and high speed movements were more likely to damage humerus-radio-ulnar joint than in working and jumping animals. This is understandable because this joint remains exposed to trauma during the match.

All records of animals used in this study were obtained from the horse farms and/or riding centers. Although our results corroborate with previous studies, the number of individuals from different physical activity groups was less than expected. This was due, in part, because many animals did not meet the inclusion criteria, which was a conclusive imaging exam. Another limitation was the large number of different veterinarians who carried out the exams. They could have different levels of expertise on the subject or could not even been considered experts in the area.

Identifying orthopedic injuries can determine the risk factors inherent to each athletic modality in order to propose changes that will reduce or abolish such risks (McKERNEY et al., 2013). Thus, one can increase animal's career length, athletic ability and reduce costs and losses due to lameness and poor performance.

International studies of this scope are rare and may not reflect our factors such as environment, training, management or competition arena, hence the importance of regional studies that indicate lesions and risk factors characteristics that cause losses in the equestrian sphere.

We conclude that there is a relationship between location and type of injury and physical activity. Racing horses were predominantly young animals, with higher prevalence of orthopedic injuries due to traumatic events, such as tendonitis, desmitis and fractures. Age-related degenerative diseases, such as joint disease were more common among physical activities that require longer training and in which animals had longer athletic career, such as jumping, polo pony and working predominates. Joint disease was the most common injury in dressage horses, and desmitis in horses that performed western sports. Orthopedic injures presented higher percentage in hind limbs for dressage and western modalities horses, while they were higher on forelimbs for racing, polo pony, jumping and working animals.

\section{BIOETHICS AND BIOSSECURITY COMMITTEE APPROVAL}

This study was approved by the Comissão de Ética no Uso de Animais de Faculdade de Medicina Veterinária e Zootecnia, UNESP, Botucatu, under protocol number 213/2012 - CEUA.

\section{AKNOWLEDGEMENTS}

To Coordenação de Aperfeiçoamento de Pessoal de Nível Superior (CAPES) for granting the scholarship.

\section{REFERENCES}

BAILEY, C.J. et al. Risk factors associated with musculoskeletal injuries in Australian Thoroughbred racehorses. Preventive Veterinary Medicine, v.32,n.1,p.47-55, 1997. Available from: $<$ http:// 
www.sciencedirect.com/science/article/pii/S0167587797000093>. Accessed: nov. 2014. doi: 10.1016/S0167-5877(97)00009-3.

BAXTER, G.M. Adams and Stashak's lameness in horses. 6.ed. Chichester: John Wiley \& Sons, 2011. xxviii + 1242p. ISBN 978-08138-1549-7

BOSWELL, R.P. et al. Lameness in the show hunter and show jumper. In: ROSS, M.W.; DYSON, S.J. (Ed.). Diagnosis and management of lameness in the horse. Saint Louis: Saunders, 2003. Chap.116, p.965-975.

BURDEN, E.R. et al. Objective assessment of gait asymmetry in polo ponies. Equine Veterinary Journal, v.45, n.S44, p. 9, 2013 ISSN 2042-3306. Available from: $<$ http://onlinelibrary.wiley.com/ doi/10.1111/evj.12145_22/abstract>. Accessed: nov. 2014. doi: $10.1111 /$ evj.12145 22 .

BURN, J.F. et al. The effect of speed and gradient on hyperextension of the equine carpus. Veterinary Journal, v.171, n.1, p.169-171, 2006. Available from: $<$ http://dx.doi.org/10.1016/j. tvj1.2004.10.010>. Accessed: nov. 2014

CHENEY, J.A. et al. Cannon-bone fracture in the thoroughbred racehorse. Medical and Biological Engineering, v.11, n.5, p.613620, 1973. Available from: $<$ http://link.springer.com/article/10.10 07\%2FBF02477408?LI=true> . Accessed: nov. 2014. doi: 10.1007/ BF02477408

COGGER, N. et al. Incidence rate of musculoskeletal injuries and determinants of time to recovery in young Australian Thoroughbred racehorses. Australian Veterinary Journal, v.86, n.12, p.473-480, 2008. Available from: $<\mathrm{http}$ ://onlinelibrary.wiley. com/doi/10.1111/j.1751-0813.2008.00359.x/full>. Accessed: nov. 2014. doi: 10.1111/j.1751-0813.2008.00359.x

CONTINO, E.K. et al. Prevalence of radiographic changes in yearling and 2-year-old Quarter Horses intended for cutting. Equine Veterinary Journal, v.44, n.2, p.185-195, 2012. ISSN 2042-3306. Available from: <https://www.ncbi.nlm.nih.gov/ pubmed/21815932>. Accessed: jul. 2015. doi: 10.1111/j.20423306.2011.00432.x

COUROUCÉ-MALBLANC, A. et al. Abnormal radiographic findings in 865 French standardbred trotters and their relationship to racing performance. Equine Veterinary Journal, v.38, n.S36, p.417-422, 2006. Available from: <https://www.ncbi.nlm.nih.gov/ pubmed/17402458>. Accessed: abr.2013. doi: 10.1111/j.20423306.2006.tb05579.x.

DABAREINER, R.M.; CARTER, G.K. Barrel-racing horses. In: ROSS, M.W.; DYSON, S. (Eds.). Diagnosis and management of the lame horse. St Louis:Saunders/Missouri: Elsevier, 2003. p.1021-1026. ISBN: 978-0-7216-8342-3.

DABAREINER, R.M. et al. Musculoskeletal problems associated with lameness and poor performance among horses used for barrel racing: 118 cases (2000-2003). Journal of the American Veterinary Medical Association, v.227, n.10, p.1646-1650, 2005. Available from: <http://avmajournals.avma.org/doi/abs/10.2460/ javma.2005.227.1646>. Accessed: jun. 2012. doi: 10.2460/ javma.2005.227.1646.

DALLAS, R.S. Musculoskeletal injury in arabian racehorses: a study of injury distribution and prevalence in one training yard in the United Kingdom (2005-2012). Equine Veterinary
Journal, v.45, n.S44, p.10-10, 2013. ISSN 2042-3306. Available from: <http://onlinelibrary.wiley.com/doi/10.1111/evj.12145 23/ abstract $>$. Accessed: jun. 2014. doi: 10.1111/evj.12145_23.

DYSON, S. Lameness and poor performance in the sport horse: dressage, show jumping and horse trials. Journal of Equine Veterinary Science, v.22, n.4, p.145-150, 2002. Available from: <http://dx.doi.org/10.1016/ S0737-0806(02)70139-1>. Accessed: jan. 2012.

Diagnosis and management of common suspensory lesions in the forelimbs and hindlimbs of sport horses. Clinical Techniques in Equine Practice, v.6, n.3, p.179-188, 2007. Available from: <http:// dx.doi.org/10.1053/j.ctep.2007.08.004>. Accessed: apr. 2012.

EVANS, D.L.; WALSH, J.S. Effect of increasing the banking of a racetrack on the occurrence of injury and lameness in standardbred horses. Australian Veterinary Journal, v.75, n.10, p.751-752, 1997. Available from: <http://onlinelibrary.wiley.com/ doi/10.1111/j.1751-0813.1997.tb12261.x/abstract>. Accessed: jan. 2015. doi: 10.1111/j.1751-

HERNANDEZ, J. et al. Race-start characteristics and risk of catastrophic musculoskeletal injury in Thoroughbred racehorses. Journal of the American Veterinary Medical Association, v.218, n.1, p.83-86, 2001. Available from: <http://avmajournals. avma.org/doi/abs/10.2460/javma.2001.218.83>. Accessed: jan. 2015. doi:10.2460/javma.2001.218.83.

KOLD, S.E.; DYSON, S.J. Lameness in the dressage horse. In: DYSON, S.J.;ROSS, M.W. (Eds.). Diagnosis and management of lameness in the horse. Saint Louis: Saunders, 2003. Chap.117, p.975-983. ISBN: 978-0-7216-8342-3.

LOBATO, G.D.V.C. Avaliação clínica e ultrassonográfica do tendão e da bursa do músculo bíceps braquial em cavalos de polo. 2013. 49f. (Mestrado em Clínica e Reprodução Animal), Faculdade de Medicina Veterinária, Universidade Federal Fluminense, RJ, 2013

MARNERIS, D.; DYSON, S.J. Clinical features, diagnostic imaging findings and concurrent injuries in 71 sports horses with suspensory branch injuries. Equine Veterinary Education, v.26, n.6, p.312-321, 2014. ISSN 2042-3292. Available from: < http:// onlinelibrary.wiley.com/doi/10.1111/eve.12175/full>. Accessed: jun. 2015. doi:10.1111/eve. 12175 .

MCGOWAN, C.M. et al. Incidence of exertional rhabdomyolysis in polo horses in the USA and the United Kingdom in the 1999/2000 season. Veterinary Record, v.150, n.17, p.535537, 2002. Available from: <http://veterinaryrecord.bmj.com/ content/150/17/535.short $>$. Accessed: nov. 2014. doi: 10.1136/ vr.150.17.535

MCKERNEY, E. et al. Fatal musculoskeletal injuries of the metacarpophalangeal and metatarsophalangeal (fetlock) joints in California racehorses: one hundred thirty-nine cases. In: ANNUAL CONVENTION OF THE AMERICAN ASSOCIATION OF EQUINE PRACTITIONERS, 59.,2013, Nashville, Tennessee, USA. Proceedings... Nashville: American Association of Equine Practitioners (AAEP), p. 402, 2013.

MEERSHOEK, L.S. et al. Forelimb tendon loading during jump landings and the influence of fence height. Equine Veterinary Journal, v.33, n.S33, p.6-10, 2001. Available from: <http:// onlinelibrary.wiley.com/doi/10.1111/j.2042-3306.2001.tb05349.x/ full>. Accessed: apr. 2014. doi: 10.1111/j.2042-. 
MENARIM, B.C. et al. Radiographic abnormalities in barrel racing horses with lameness referable to the metacarpophalangeal joint. Journal of Equine Veterinary Science, v.32, n.4, p.216-221, 2012. Available from: <http://dx.doi.org/10.1016/j. jevs.2011.09.064>. Accessed: nov. 2012.

MITCHELL, R.D. Distal limb lameness in the sport horse: a clinical approach to diagnosis. In: ANNUAL CONVENTION OF THE AMERICAN ASSOCIATION OF EQUINE PRACTITIONERS, 59.,2013, Nashville, Tennessee, USA. Proceedings... Nashville: American Association of Equine Practitioners (AAEP), 2013. p.244-249.

MURRAY, R.C. et al. Association of type of sport and performance level with anatomical site of orthopaedic injury diagnosis. Equine Veterinary Journal, v.38, n.S36, p.411-416, 2006. Available from: $<$ https://www.ncbi.nlm.nih.gov/pubmed/17402457>. Accessed: jan. 2012. doi: 10.1111/j.2042-3306.2006.tb05578.x

Identification of risk factors for lameness in dressage horses Veterinary Journal, v.184, n.1, p.27-36, 2010. Available from: $<$ http://dx.doi.org/10.1016/j.tvj1.2009.03.020>. Accessed: nov. 2015.

O'MEARA, B. et al. An investigation of the relationship between race performance and superficial digital flexor tendonitis in the Thoroughbred racehorse. Equine Veterinary Journal, v.42, n.4, p.322, 2010. ISSN 0425-1644. Available from: <http:// onlinelibrary.wiley.com/doi/10.1111/j.2042-3306.2009.00021.x/ full>.Accessed: jan. 2015. doi: 10.1111/j.2042-3306.2009.00021.x.

OWEN, K.R. et al. Identification of risk factors for traumatic injury in the general horse population of north-west England, Midlands and north Wales. Equine Veterinary Journal, v.44, n.2, p.143-148, 2012. Available from: <http://onlinelibrary.wiley.com/ doi/10.1111/j.2042-3306.2011.00387.x/full>. Accessed: jun. 2015. doi: $10.1111 / \mathrm{j} .2042-3306.2011 .00387 . \mathrm{x}$

PARKIN, T.D. Epidemiology of racetrack injuries in racehorses. Veterinary Clinics of North America: Equine Practice, v.24, n.1, p.1-19, 2008. Available from: <http://dx.doi.org/10.1016/j. cveq.2007.11.003>. Accessed: jan. 2013

PILSWORTH, R.C. et al. Fracture of the wing of the ilium, adjacent to the sacroiliac joint, in thoroughbred racehorses. Equine Veterinary Journal, v.26, n.2, p.94-99, 1994. Available from: $<$ http://onlinelibrary.wiley.com/doi/10.1111/j.2042-3306.1994. tb04343.x/abstract>. Accessed: apr. 2012. doi: 10.1111/j.20423306.1994.tb04343.x.

POOL, R.R.; MEAGHER, D.M. Pathologic findings and pathogenesis of racetrack injuries. Veterinary Clinics North America: Equine Practice, v.6, n.1, p.1-30, 1990. Available from: $<$ http://europepmc.org/abstract/med/2187565>. Accessed: apr. 2012. PMID:2187565.

RAMZAN, P.H.L. et al. Subclinical ultrasonographic abnormalities of the suspensory ligament branch of the athletic horse: asurvey of
60 Thoroughbred racehorses. Equine Veterinary Journal, v.45, n.2, p.159-163, 2013. Available from: <https://www.ncbi.nlm.nih. gov/pubmed/22607323>. Accessed: jun. 2014. doi: 10.1111/j.20423306.2012.00588.x.

RIGGS, C.M. Fractures -a preventable hazard of racing thoroughbreds? Veterinary Journal, v.163, n.1, p.19-29, 2002. Available from: < doi:10.1053/tvj1.2001.0610>. Accessed: nov. 2014.

Clinical problems in dressage horses: identifying the issues and comparing them with knowledge from racing. Veterinary Journal (London, England: 1997), v.184, n.1, p.1-2, 2010. Available from: $<$ http://europepmc.org/abstract/med/19716322>. Accessed: nov. 2014. doi: 10.1016/j.tvj1.2009.07.027.

SCHAMBARDT, H.C. et al. External loads on the limbs of jumping horses at take-off and landing. American Journal of Veterinary Research, v.54, n.5, p.675-680, 1993. Available from: $<$ https://www.ncbi.nlm.nih.gov/pubmed/8317758>. Accessed: jan. 2013. PMID: 8317758.

SCHOEN, A.M. Equine acupuncture: incorporation into lameness diagnosis and treatment. In: AMERICAN ASSOCIATION OF EQUINE PRACTIONERS ANNUAL CONVENTION, 59., 2000, San Antonio, Texas, USA. Proceedings... And Antonio: IVIS, 2000. p.80-83.

SCOTT, M. Musculoskeletal injuries in nonracing quarter horses. Veterinary Clinics of North America: Equine Practice, v.24, n.1, p.133-152, 2008. Available from: $<$ http://dx.doi.org/10.1016/j. cveq.2007.11.006>. Accessed: apr. 2012.

STOVER, S.M. The epidemiology of Thoroughbred racehorse injuries. Clinical Techniques in Equine Practice, v.2, n.4, p.312-322, 2003. Available from: <http://dx.doi.org/10.1053/j. ctep.2004.04.003>. Accessed: apr. 2012.

TIPTON, T.E. et al. Superficial digital flexor tendonitis in cutting horses: 19 cases (2007-2011). Journal of the American Veterinary Medical Association, v.243, n.8, p.1162-1165, 2013. Available from: <http://avmajournals.avma.org/doi/abs/10.2460/ javma.243.8.1162>. Accessed: nov. 2014. doi: 10.2460/ javma.243.8.1162.

TURLEY, S.M. et al. Microstructural changes in cartilage and bone related to repetitive overloading in an equine athlete model. Journal of Anatomy, v.224, n.6, p.647-658, 2014. ISSN 14697580. Available from: $<$ http://onlinelibrary.wiley.com/doi/10.1111/ joa.12177/full>. Accessed: jan. 2015. doi:10.1111/joa.12177.

WILLIAMS, R.B. et al. Racehorse injuries, clinical problems and fatalities recorded on British racecourses from flat racing and National Hunt racing during 1996, 1997 and 1998. Equine veterinary journal, v.33, n.5, p.478-486, 2001. Available from: <http://onlinelibrary.wiley.com/ doi/10.2746/042516401776254808/abstract $>$. Accessed: nov. 2014. doi: $10.2746 / 042516401776254808$ 